Dokuz Eylül Üniversitesi-Mühendislik Fakültesi

Fen ve Mühendislik Dergisi

Cilt 20, Sayı 60, Eylül, 2018
Dokuz Eylul University-Faculty of Engineering Journal of Science and Engineering Volume 20, Issue 60, September, 2018

DOI: $10.21205 /$ deufmd. 2018206068

\title{
Üniversite Öğrencilerinin Ders Devamlarının Takibine Yönelik Bilgi Sistemi
}

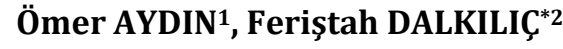 \\ ${ }^{1}$ Dokuz Eylül Üniversitesi, İktisadi ve İdari Bilimler Fakültesi, Bilgi İșlem Birimi, İzmir \\ (ORCID: 0000-0002-7137-4881) \\ 2Dokuz Eylül Üniversitesi, Mühendislik Fakültesi, Bilgisayar Mühendisliği Bölümü, İzmir \\ (ORCID: 0000-0001-7528-5109)
}

(Alınış / Received: 01.02.2018, Kabul / Accepted: 25.04.2018, Online Yayınlanma / Published Online: 15.09.2018)

Anahtar Kelimeler Özet: Üniversite öğrencilerinin derslere devamlarının akademik RFID kart, Öğrenci ders devam, Devam takip sistemi, Yoklama başarıya etkisi birçok akademik çalışma ile irdelenmiş ve derslere devam eden öğrencilerin başarı oranlarının daha yüksek olduğu tespit edilmiştir. Devam durumları birçok yükseköğretim kurumunda klasik yöntemlerle takip edilmektedir. Gelișen teknoloji ile öğrencilerin ders devam takibini bilgi sistemleri vasıtası ile yapmak mümkün olmuştur. Bu çalışmada, temassız akıllı kartlar kullanılarak öğrenci devam takip sistemi tasarlanmış ve geliştirilmiştir. Sistemin yönetimi ve devam durumlarının takibi için web uygulama ara yüzleri geliştirilmiştir. Sistem ile ders devam takibi daha hızlı ve güvenilir hale getirilmiştir. $\mathrm{Bu}$ sisteme bütünleşmiş veri madenciliği modülü ile toplanan veriler analiz edilmekte, böylece ileriye dönük önlemler alınabilmekte ve geliştirmeler yapılabilmektedir.

\section{University Student Attendance Management System}

\begin{tabular}{ll}
\hline Keywords & Abstract: The impact to the academic achievement of the \\
RFID card, & university students' attendance to the courses was examined by \\
Student course & many academic studies and it has been found that the success \\
attendance, & rates of the students attended to the courses are higher. \\
Attendance & Attendance statuses of students are tracked by classical methods \\
tracking system, & in many higher education institutions. It is possible to track \\
Roll call & student attendance utilizing current information systems. In this \\
& paper, an attendance tracking system has been designed and \\
developed by using contactless smart cards. Web applications & for management of the system and tracking the student \\
& attendance have been developed. Tracking student attendance \\
& has become faster and more reliable with the system. The \\
& collected data is analyzed with the data-mining module \\
integrated into this system, thus proactive measures can be & taken and improvements can be made.
\end{tabular}

*Sorumlu yazar:feristah@cs.deu.edu.tr 


\section{Giriş}

Yükseköğretim kurumlarımızda yürütülen eğitim öğretim faaliyetlerinin temel odak noktası, öğrencilere gerekli bilgi birikimi kazandırmak, kazanılan akademik yetkinliğin düzeyini ölçmek, ölçüm sonuçları ile öğrencinin gelecek yaşamına yön vermek ve öğrencilerin kendilerine has özelliklerini ön planda tutarak onları başarılı olacakları alanlara yönlendirmektir [1]. Bu odak noktalarını dikkate alarak yürütülen tüm çalıșmalar sonucunda öğrencinin gelecek yaşamında başarılı, yetkin ve faydalı bir birey olması beklenir. Öğrencinin öğrenim hayatı boyunca bu yetkinliklere sahip olmak için etkin ve istekli olması elde edilen sonucu șekillendirmektedir. Bunların yanında öğrencilerin öğrenim hayatlarında başarılı olmalarını etkileyen daha birçok neden vardır [1-3]. Bu nedenler incelendiğinde öğrencinin derslere devam etmemesinin veya etkin bir şekilde derste yer almamasının başarı düzeyini etkilediği görülmektedir. $\mathrm{Bu}$ tespit göz önünde bulundurulduğunda öğrencinin derslere devam etmemesi akademik başarısını doğrudan etkileyen bir etmen olarak karşımıza çıkmaktadır [4].

Devamsızlığın nedeni araștırıldığında fiziksel, psikolojik ve toplumsal birçok değişkenin bu davranışta etkili olduğu görülmektedir. Buradan da anlașılacağı üzere devamsızlık davranışı çok farklı nedenlerle ortaya çlkabilmektedir [5]. Derslere devamsızlık, öğrencinin sosyal yaşamı ile akademik durumunu etkileyebilmektedir. Eğitim öğretim yapılan kurumun fiziki koșulları, mevsim ve hava şartları, bireyin kendisi veya çevresindeki bireylerde doğabilecek sağlık sorunları, ulaşım ve konaklama gibi sorunlar ile bireyin yetersizlikleri devamsızlık nedenleri olarak verilebilir [5]. Öğrencilerin derslere katılmamayı bir alışkanlık haline getirmeleri, akademik bașarı anlamında diğer öğrencilerden geri kalmalarına, ders içeriklerini anlamak ve uygulamakta zorluk çekmelerine, mezuniyet sürelerinin uzaması, eğitimlerine ara verme veya tamamen sonlandırmalarına neden olabilmektedir [4-7]. Tüm bu nedenlerden dolayı devamsızlık davranışlarının takibi önemli hale gelmiștir. Günümüzde eğitim öğretim kurumlarının birçoğunda derse katılım takibi geleneksel yöntemlerle yapılmaktadır. Bu durum, eğitim öğretim faaliyetleri için ayrılabilecek kaynakların verimsiz bir şekilde kullanılmasına neden olmaktadır. Zaman, iş gücü ve para bu kaynaklar arasında sayılabilir.

Günümüzde insan sayısının ve yeteneklerinin yetersiz kaldığı birçok alanda işlemleri kolaylaştırmak, denetlemek ve yönetmek için bilgisayarlı otomasyon kontrol sistemleri yaygin olarak kullanılmaktadır. Teknolojideki bu gelişmeler eğitim öğretim faaliyetlerini de etkilemektedir. Bilgisayar ve otomasyon sistemlerinin kullanımı son yıllarda eğitim öğretim kurumlarında yaygınlaşarak artmaktadır [8]. Bu yaygınlaşmanın bir sonucu olarak öğrencilerin derslere devam durumlarını takip etmek için otomasyon kullanımı da olanaklı hale gelmiştir. Ders devam kontrolü otomasyon sistemleri de geleneksel yöntemlerin yerini alarak teknolojinin eğitim alanındaki yansımalarından birisi haline gelmektedir.

Türkiye İstatistik Kurumu 2017 yllı verilerine göre hanelerin \%80,7'si internet erișimine sahiptir. Yine aynı araștırmaya göre hanelerdeki bilgisayar kullanımı \%56,7, internet kullanımı ise $\% 66,8$ olmuștur [9]. Bu bilgilerden de anlaşılacağı üzere toplum teknoloji ile iç içe yașamaya bașlamıștır. Teknolojinin özümsendiği bu dönemde her türlü işlemi bilgisayarlar vasıtası ile internet üzerinden yapabilme ve sorgulayabilme ihtiyacı artmaktadır. Mevcut teknolojik imkânlar ile bireylerin ihtiyaçları bir 
arada düşünüldüğünde, hizmet arzının bu altyapıları kullanması ve kişilerin de bu teknolojileri kullanabilmesi gerekliliği her geçen gün artmaktadır. İnternet altyapısının ve erişilebilirliğinin yukarıda belirtilmiş istatistikler dikkate alındığında ciddi seviyelere ulaştığı görülmektedir. Öğrencilerin derse katılım durumlarının takibini internet üzerinden yapabilmeleri bu altyapının eğitim alanında kullanımına bir örnek olarak düşünülebilir. Tüm bu ihtiyaçlar nedeni ile çevrimiçi takip edilebilen sistem tasarımları ön plana çıkmıştır. Bu çalışmada, sistem girdilerinin internet altyapısı ile toplanıp, özel olarak tasarlanmış veri tabanında saklanacağl, sistem girdilerinin öğrencilere ve öğretim elamanlarına raporlanmasının internete açık sistemler vasıtası ile yapılacağı bir öğrenci devam takip sisteminin geliştirilmesi amaçlanmıştır. Böylece üniversitemiz bünyesinde teknolojik alt yapıların kullanımının artırılması ve zaman, iş gücü, para gibi maliyetlerden tasarruf edilmesi hedeflenmiştir. Geliştirilen sistemin fakülte bünyesinde kullanılmasıyla, öğrenci devam takibinin çok daha hızlı ve güvenilir bir şekilde gerçekleştirilmesi sağlanmıştır.

\section{2. İlgili Çalışmalar}

Geçmiş çalışmalar incelendiğinde, birçok farklı teknoloji kullanılarak öğrenci devam takip sistemlerinin geliştirilmeye çalışıldığı görülmüştür. Takip işlemleri, parmak izi tanıma, RFID (RadioFrequency Identification - Radyo Frekans1 ile Tanımlama), akıllı kart ve göz iris tarama gibi çeșitli teknolojiler kullanılarak yapılabilmektedir. Amerika Birleşik Devletleri'nde birçok yükseköğretim kurumunda yemek salonları, sinıflar ve yurtlardaki takip ve bilgi sistemlerinde, ayrıca personel devam takip işlemlerinde parmak izi tanıma sistemleri gibi teknolojiler kullanılmaktadır. Biyometrik veri ile tanıma teknolojisini Georgia Üniversitesi
1974 yılından bu yana birçok uygulama alanında kullanmaktadır. Yine aynı şekilde West Alabama Üniversitesi'nde parmak izi ile tanımlama teknolojisi uzaktan eğitim alan öğrencilerin bilgisayar üzerinden katıldıkları sınavlar esnasında kimliklerinin tespit edilmesi için kullanılmıştır. Bentley Üniversitesi, 4000 öğrencisinin dizüstü bilgisayarları ile fakültede kullanılan bilgisayarlarda parmak izi tanıma sistemi kullanmaktadır. Rutgers Üniversitesinde aynı sistem, araştırma yapılan cihazları izlemek ve yönetmek için kurulmuştur [10]. Kainz vd. seminer ve konferans gibi toplantılara katılan öğrencilerin takibi için görsel işlemler yapan bir sistem önermişlerdir. $\mathrm{Bu}$ sistemde yüz tanıma algoritmaları vasıtası ile kişiler tespit edilmekte ve mevcut veri tabanında bulunan verilerle karşılaştırılmaktadır. $\mathrm{Bu}$ çalışma öğrenci sayısı düşük toplantılarda ve siniflarda test edilebilmiştir [11].

Benyo vd. NFC teknolojisini kullanarak, merkezi sunucu ile kablosuz bağlantıya sahip 30 adet terminal üzerinden öğrenci ders devam takibini gerçekleştiren bir sistem tasarlamışlardır. $\mathrm{Bu}$ sistemi Budapeşte üniversitesinde 1000 den fazla öğrencinin bulunduğu bir alanda gerçekleştirmişlerdir [12]. Krisha vd. ise, öğrencilerin üzerinde yer alan RFID etiketlerini okuyucu ve GSM modülü vasıtası ile gözlemlemeye ve kayıt altına almaya yarayan bir takip sistemi prototipi tasarlamışlardır [13].

Silva vd. yaptıkları çalışmada Ethernet üzerinden RFID teknolojisini kullanarak bir devam takip sistemi mimarisi ve prototipi önermişlerdir. $\mathrm{Bu}$ öneride, tüm sınıflara yerleştirilecek olan RFID okuyucuları ile dağıtık bir yapı kurulması öngörülmüştür. RFID teknolojisi kullanıldığından dolayı otomatik bir şekilde katılım takibi yapılabilmektedir [14]. $\mathrm{Bu}$ sistem değerlendirildiğinde devam takibinin sağlamasının 
yapılmasının çok mümkün olmadığı görülmektedir. Özellikle büyük ve kalabalık sınıflarda içeride kaç öğrenci olduğunun takibinin yapılması bu sistemle mümkün olmayacaktır. Bir öğrencinin arkadaşına ait bir RFID öğrenci kimlik kartı ile sınıfa gelmesi durumunda, bunun tespiti yapılamayacaktır. RFID kart okuyucunun okuma mesafesinin 8-10 metre gibi mesafelere ulaşabildiği düşünülür ise bu uygulamadaki mimarinin okuma mesafesi düşük okuyucularla kurulması gereği ön plana çıkmaktadır. Dersin ögretim elemanı tarafından, okuyucuya birden fazla RFID etiketinin tek öğrenci tarafından okutulmasının önüne geçilmesi ve kişinin sadece kendine ait etiket ile yoklamaya katılması kontrol edilebilme imkânı sağlanmalıdır. $\mathrm{Bu}$ mimaride kişinin kendini doğrulama imkânı ancak bu şekilde sağlanabilecektir. Patel vd. çalışmalarında RFID teknolojisinden faydalanarak çevrimiçi öğrenci devam takip sistemi önermişlerdir [15]. Bu çalışmadaki sistem hızlı, tam otomatik, fiziksel temas gerektirmeyen, kâğıt üzerindeki işlemleri azaltan, zaman konusunda tasarruf sağlayan, çevrimiçi bir yapı sunmasına rağmen Silvia vd.'nin yaptıkları çalışmada olduğu gibi başkasının yerine derse katılım ve bir öğrencinin birden fazla öğrencinin etiketini taşıma sorununa bir çözüm üretilememiştir. Çakır ve Kaygısız geliştirdikleri ve önerdikleri modelle öğrenci kimlikleri üzerinde yer alacak RFID etiketleri vasıtası ile öğrenci devamını kontrol etmeyi amaçlamıșlardır. Her sınıfın kapısında yer alacak RFID okuyucular vasitasıyla, öğrencinin sınıfa girişinde ders saati ve dersliğin eşleștirilerek öğrencinin hangi derse katıldığının tespit edilmesi ve aynı zamanda öğretim elemanının kaydının tutulması hedeflenmiştir [16]. Bu çalışmada da önceki çalışmalarda ki sorunlar çözüme kavuşturulmamıştır. Bu duruma ek olarak devam takip işlemi dersin öğretim elemanı tarafından başlatılmadığı için acil durumlarda yapılan derslik değişimleri, öğrencin yoklamaya katılıp ders başlamadan veya başladıktan sonra dersi terk etmesi durumlarında hala derse katılmış gibi görünmesi gibi problemleri ortadan kaldırmamaktadır.

$\mathrm{Bu}$ çalışma ile RFID teknolojisi temellerine dayanan, öğretim elemanının yoklamayı yönetebileceği ve öğrencileri yoklama süresince gözlemleyebileceği bir sistem önerilmiştir. Böylece ders devam takibinin daha hılı ve güvenli bir şekilde gerçekleştirilmesi mümkün hale gelmiştir.

\section{3. Öğrenci Devam Takip Sistemi}

Okullar eğitim öğretim faaliyetlerinin yürütülmesi için oluşturulmuş kontrollü ve özel ortamlardır. $\mathrm{Bu}$ ortamda öğrencilere verilmek istenen bilgi, beceri ve deneyim önceden planlanmıştır. Bu değerlerin öğrenciye kazandırılması için çeşitli öğretim teknikleri planlı bir şekilde uygulanır [5]. Tüm bunların sonunda öğrencide oluşması beklenen sonuçların ölçümü yapılır. Bu ölçüm sonuçları öğrencinin başarısını ortaya koyar. Öğrencilerin başarı düzeylerini etkileyen birçok etmen bulunmaktadır. $\mathrm{Bu}$ konuda da birçok akademik çalışma yapılmıştır $[4,5,17-20]$. Yapılan bu çalışmalarda görülebileceği gibi öğrencinin derslere katılımı akademik başarıyı etkilemektedir. Bunlar göz önünde bulundurulduğunda akademik başarının arttırılması için onu etkileyen faktörlerin incelenmesi ve izlenmesi önemli bir olgu olarak karşımıza çlkmaktadır.

Bu çalıșmadaki uygulama Dokuz Eylül Üniversitesi İktisadi ve İdari Bilimler Fakültesi'nde gerçekleştirilmiştir. Uygulamanın geliştirilme gerekçesi Dokuz Eylül Üniversitesi Ön Lisans ve Lisans Öğretim ve Sınav Yönetmeliği'nin 13 Ağustos 2012 tarihli 28383 sayılı 
Resmi Gazetede yayınlanan 20. Maddesidir. $\mathrm{Bu}$ maddeye göre bir öğrencinin bir dersin yarıyıl sonu/yılsonu ve bütünleme sınavlarına girebilmesi için, aşağıdaki şartları yerine getirmesi gerekir:

a) Teorik derslerin ve öğretim üyeleri veya elemanları tarafindan sinıfta yapılan uygulamaların en az \%70'ine katılmış olması,

b) Laboratuvar, proje, atölye, sınıf dışında yapılan uygulamalar ve benzeri yarıyıl içi veya yıl içi çalışmaların en az \%80'ine katılmış olması [21].

\subsection{Sistem bileşenleri}

Sistem, öğrenci kimlik kartlarının her sınıfin kapısında yer alan RFID kart okuyuculara okutulması ve bu kayıtların öğrencilerin ilgili yarıyılda kayıtlandıkları derslerle eşleștirilmesi ilkesine dayanmaktadır. Birçok üniversitede öğrencilere dağıtılan öğrenci kimlik kartları incelendiğinde, kimlik kartlarının bu uygulama için gerekli temel teknik özelliklere sahip oldukları görülmektedir. Üniversitelerin büyük çoğunluğu, öğrencilerine kayıt esnasında Şekil 1'de yer alan ISO14443 $13.56 \mathrm{MHz}$ s50/s70 MIFARE tipinde olan temassız öğrenci kimlik kartlarını dağıtmaktadır [22].

$\mathrm{Bu}$ kartların benzersiz kart numaraları ile öğrencilerin bilgilerinin eşleştiği bir veri tabanı, üniversite Bilgi İșlem Dairesi Başkanlığı bünyesindeki ilgili birimlerde yönetilmektedir. Yeni bir kart basıldığında, kart ile ilgili bilgiler bu birim tarafından güncellenmektedir. Öğrenci kimlik kartlarının kullanımı, öğrenci devam takip sisteminin oluşturulması için önemli bir gerekliliğgi yerine getirmektedir. Öğrenci kimlik kartları, bu uygulama için kullanıcı kimlik doğrulamasının güvenlik simgesini (security token) oluşturmaktadır [23].

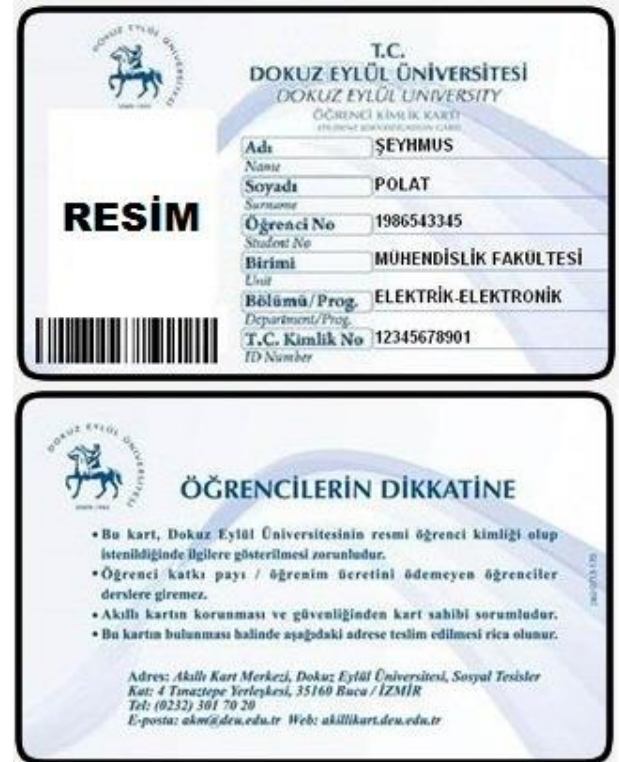

Şekil 1. Dokuz Eylül Üniversitesi öğrenci kimliği [4]

Öğrenci kimliklerinin okutulması ve bu bilgilerin sorgulanması işlemi için farklı birçok donanım kullanılabilir. Arduino [24] ve Raspberry Pi [25] gibi cihazlar ile MFRC522 [26] vb. kart okuyucu modülleri entegre edilerek çözümler geliştirilebileceği gibi, bu iş için özel olarak üretilmiş donanım çözümleri de kullanılabilir. Bu çalıșmada, dersliklerin kapı girişlerinin yanına ve öğrencilerin kolayca erişebilecekleri bir alana, cam kabin içine, yerleştirilmiş Şekil 2'deki MIFARE kart okuyucuları kullanılmıştır. $\mathrm{Bu}$ kart okuyucu veri haberleşmesini üzerinde yer alan 1 adet $100 \mathrm{Mb}$ tam çift yönlü (full dublex) ethernet portu vasıtası ile sağlamaktadır. Aynı zamanda üzerinde bariyer, kapı vb. yönetimi için çıkışlar mevcuttur. Bu cihaz veri güvenliği sağlamak için 3DES, AES, SHA1, RSA (yazılım seviyesinde) şifreleme yöntemlerini desteklemektedir. Diğer okuyucu çözümleri yerine bütünleşik yapida olan bu okuyucunun kullanilma nedeni yazılım çözümlerinin hazır olması, daha sağlam ve sürekli çalışması, testlerinin yapılmış olmasıdır. 


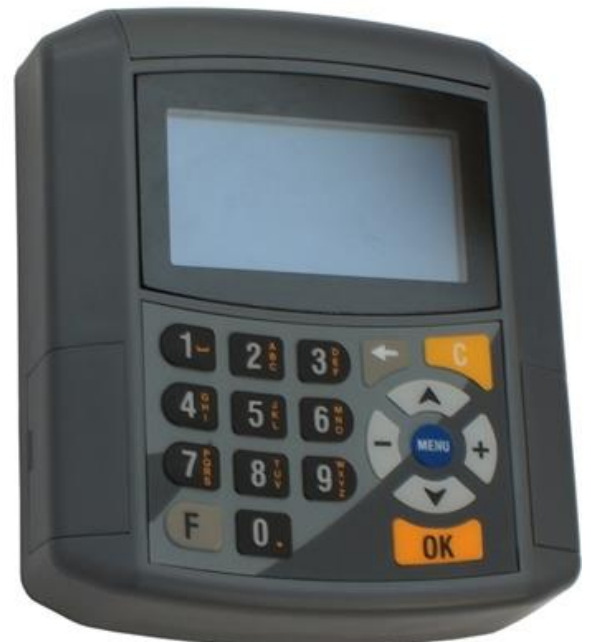

Şekil 2. Sınıf kapılarının yanına yerleștirilmiş olan MIFARE kart okuyucu [27]

Öğrenci devam takip sistemi, öğrencilerin derslere katılıp katılmadıklarını takip etmek amacı ile kurulmuştur. Ders devam takibi sadece dersin öğretim elemanı tarafından başlatılabilmekte veya sonlandırılabilmektedir. Şekil 3'te sistemin işlem akış şeması görülebilmektedir. Sistem bekleme konumunda iken siniflarda yer alan okuyucuya bir kart gösterildiğinde, ilk olarak ilgili sınıfta aktif bir yoklamanın olup olmadığı veri tabanından sorgulanır. Eğer okutulan kart bir öğretim elemanının kartı ise ve sinıfta aktif yoklama yok ise, yoklama işlemi aktif hale getirilerek başlatılır. Öğretim elemanı kartı okutulduğunda sınıfta aktif yoklama var ise ve bu yoklamayı okutulan karta sahip öğretim elemanı açtı ise yoklama kapatılır ve bekleme durumuna geri dönülür. Eğer sınıfta aktif yoklama var iken okutulan kart öğretim elemanına ait değilse bu kart numarası veri tabanına kayıt edilir. Öğretim elemanı kartı dışındaki kartların aktif yoklama yokken okutulması durumunda uyarı verilerek işlem yapılmaz. Cihaza gösterilen tüm kart bilgileri sorun oluşması durumunda incelenmek üzere ayrıca veri tabanı üzerinde başka bir tabloda da kayıt altına alınmaktadır.

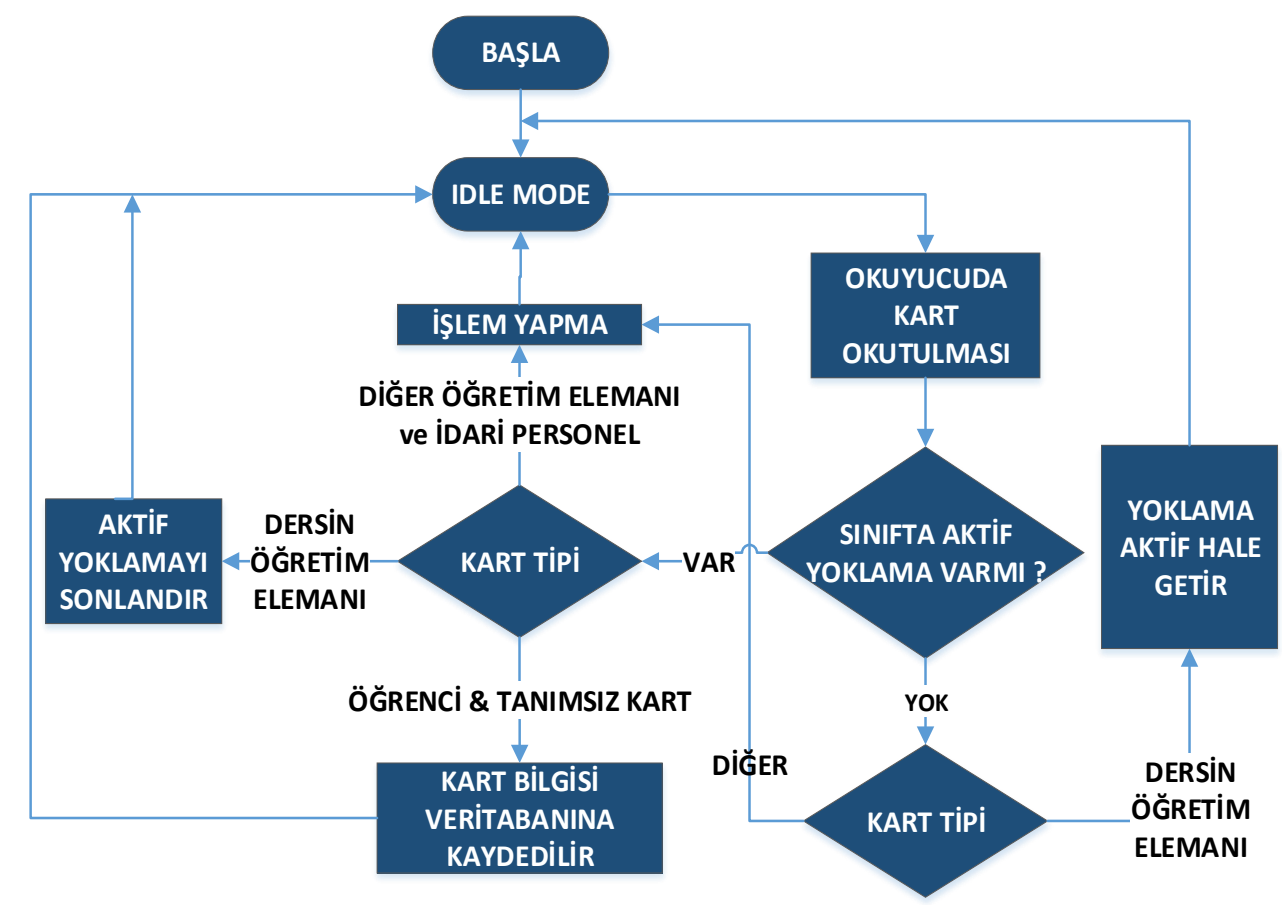

Şekil 3. Öğrenci devam takip sistemi işlem akış şeması [4] 
Veri tabanı üzerine yazlan yoklama kayıtları öğretim elemanı kart numarası, sınıf, gün, tarih ve zaman bilgileri ile yazılmaktadır. Öğrencinin derse katılıp katılmadığı, kayıtlandıkları dersler listesinde yer alan gün, derslik, öğretim elemanı ve zaman bilgileri ile eşleştirilerek yapılmaktadır.

\subsection{Sistem mimarisi}

Öğrenci devam takip sisteminin genel teknik görünümü Şekil 4'te ayrıntılı olarak verilmiştir. Sistem dört temel öğeden oluşmaktadır. Bu öğelerden ilki, siniflarda yer alan MIFARE kart okuyucularıdır. İkincisi ise tüm verilerin toplandığı ana uygulama sunucusudur. Üçüncü öğe ise, verilerin öğrenciler tarafında görüntülenmesine imkân tanıyan web sunucusudur. Son öğe, veritabanı üzerinde oluşan veriler üzerinde analizler yapmaya yarayan veri madenciliği aracıdır.

$\mathrm{Bu}$ sistem, iki farklı veri tabanı üzerine kurulmuştur. $\mathrm{Bu}$ veri tabanları birbirinden bağımsız sunucular üzerinde bulunmaktadır. İlk veri tabanı; yoklama kayıtları, ders programı, öğrencilerin kayıtlandıkları dersler ve öğrenci ile öğretim elemanı kart bilgilerinin yer aldığı tabloları içermektedir. Bu veri tabanı uygulamanın temel veri tabanıdır. $\mathrm{Bu}$ veri tabanı üzerindeki tablolar Şekil 5'te aralarındaki ilişkiler ile birlikte verilmiştir.

İkinci veri tabanı ise Web sunucusu üzerinde çalışan MySQL veri tabanıdır. $\mathrm{Bu}$ veri tabanının görevi, web sitesi üzerinden öğrencilerin ders katılım bilgilerini görebildikleri uygulamaya veri sağlamaktır. Bu veri tabanıyla, web uygulamalarına veri sağlama amacı güdülmektedir. Bu veriler tüm bilgilerin tutulduğu ana sunucu üzerindeki veri tabanı üzerinden belli dönemlerde aktarım yapılarak oluşturulmaktadır. Öğrencilerin derse katılım bilgilerini günlük olarak görmeleri yeterli olduğu varsayımı üzerine ana sunucu üzerinde toplanan anlık bilgiler ancak sistemin çalışmadığı bir dönemde web sunucusuna aktarılmaktadır. Bu aktarım için gece saat 01:15 seçilmiştir.

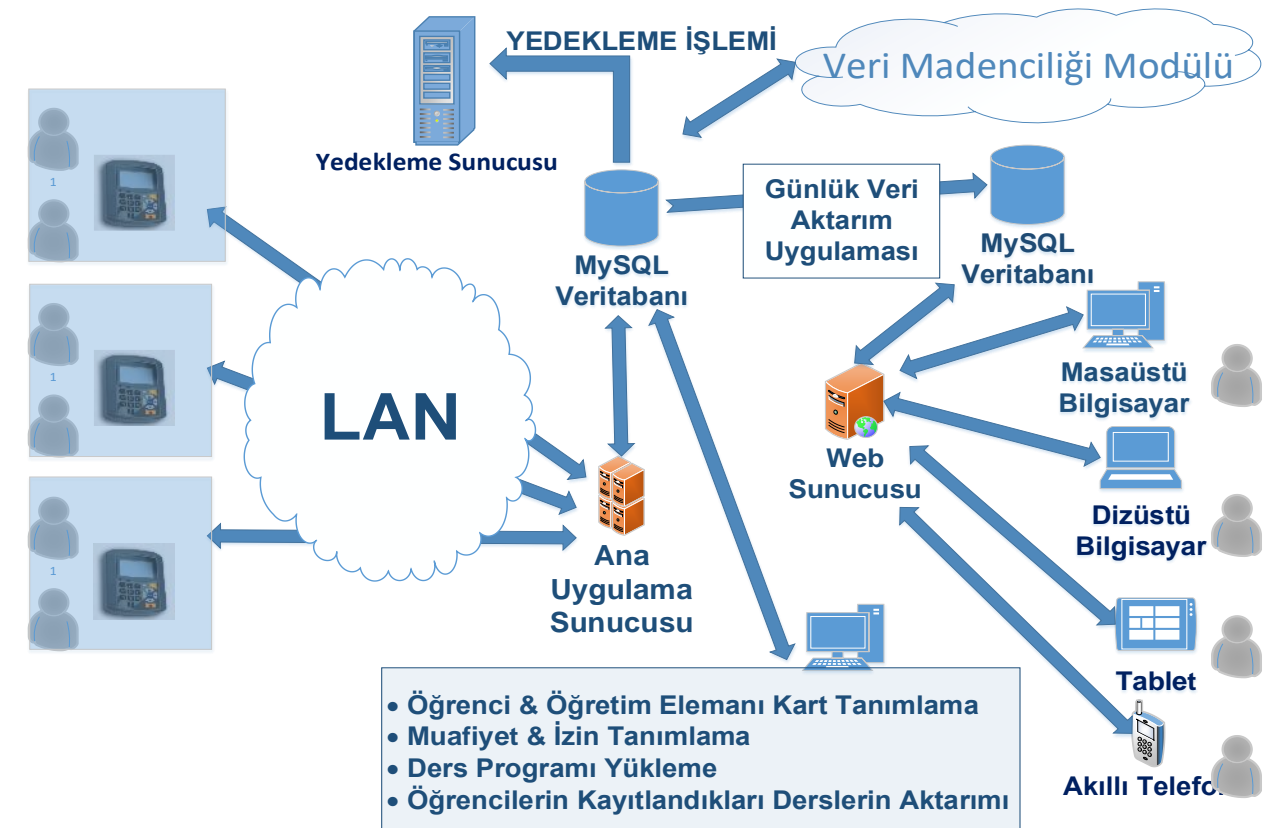

Şekil 4. Öğrenci devam takip sistemi mimarisi 
Ö. Aydın vd. / Üniversite Öğrencilerinin Ders Devamlarının Takibine Yönelik Bilgi Sistemi

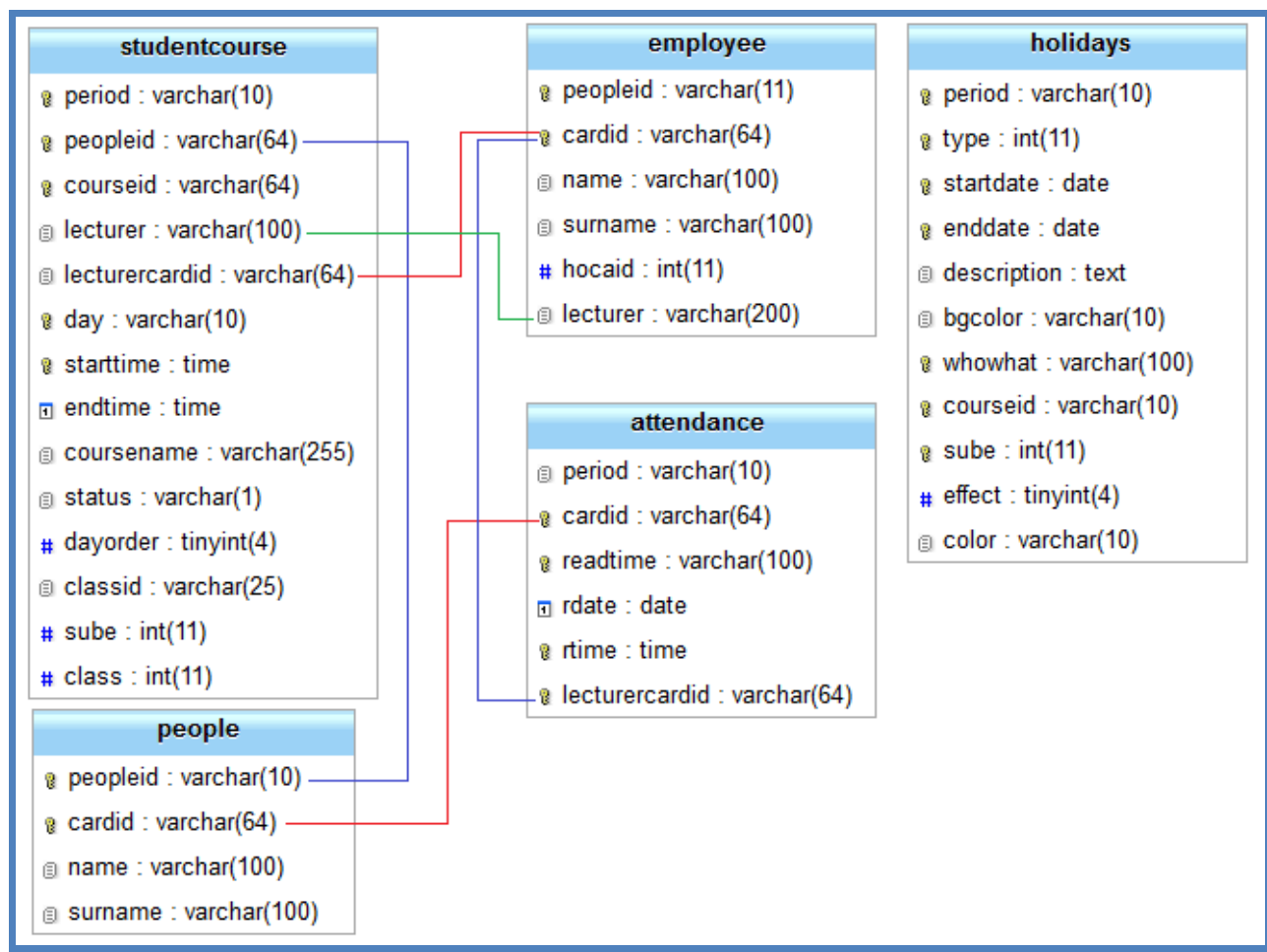

Şekil 5. Öğrenci devam takip sistemi varlık ilişki diyagramı

$\mathrm{Bu}$ saatin seçiminde hem web sunucusunun erişim istatistikleri hem de genel internet erişiminin yoğunluk istatistikleri göz önünde bulundurulmuştur. Her gün bir yazılım vasıtası ile ana sunucu veri tabanı ile web sunucusu veri tabanı arasında aktarım/eşleme sağlanmaktadır. Web sunucusu üzerinde ayrı bir veri tabanı kullanılmasına üç nedenden dolayı ihtiyaç duyulmuştur.

- Gün içinde çevrimiçi olarak birçok MIFARE kart okuyucusundan gelen verinin üzerine yazıldı ğ 1 ve devamlı veri okuma işlemlerinin yapıldığı ana veri tabanının üzerindeki yükün daha da artırılmamas1,

- Ana veri tabanı sunucusunun web üzerinden direk erişimden yalıtılması, böylece web uygulaması ile ana veri tabanına erişimde ortaya çıkabilecek güvenlik sorunlarının engellenmesi,
- Öğrencilerin derse katılım bilgilerini anlık olarak görmelerinin kritik bir önem arz etmemesi.

\subsection{Kullanıcı ara yüzü}

Öğrencilerin devam durumlarını takip edebilmeleri bu bilgi sisteminin temel öğelerinden birisidir. $\mathrm{Bu}$ işlemin her noktadan çevrimiçi olarak gerçekleştirilebilmesi günümüz dünyasında bir gerekliliktir. Bu nedenle sistem internet vasıtası ile öğrencilere açık olarak kurgulanmıştır. Öğrencilere ait üniversite bilgi sistemi kullanıcı adı (öğrenci numarası) ve şifresi ile erişim kontrolü yapılmıştır. Üniversite LDAP (Lightweight Directory Access Protocol Basit İndeks Erişim Protokolü) [28] sunucusundan ilgili öğrencinin bilgilerinin kontrolü sağlanmakta ve bu şekilde sisteme erişilebilmektedir. Erişim yapılan sunucu ile istemci arasındaki bağlantı SSL ile güvenlik altına alınmıştır. Sistem giriş ekranı ile öğrenciler devam durumlarını görüntüleyebildikleri 
sayfaya erişebilmektedirler. Öğrenciler bu ekrandan sonra açlan sayfada Şekil 6'da görüldüğü gibi kayıtlandıkları dersleri ve bu derslere ait derse katılım durumlarını hafta ve gün bazında görebilmektedirler. Aynı zamanda yoklamaya katıldıkları kayıtları bir döküm halinde görüntüleyebilmektedirler. Sistemin Google Analytics [29] üzerinde tutulan erişim istatistikleri incelendiğinde yaklaşık 100 kullanıcıdan 80 tanesinin sisteme mobil cihazlar vasıtası ile ulaştığı görülmektedir. Bu nedenle uygulama ara yüzü tepkisel (responsive) bir yapıda tasarlanmıştır. Her türlü cihaz üzerinde sorunsuz çalıșmakta ve görüntülenebilmektedir. $\mathrm{Bu}$ özellik maliyet, zaman ve platform kısitlarını ortadan kaldırmanın yanında platform bağımlı mobil uygulama geliştirmeyi gereksiz kılmıştır.

Her yeni yarıyıl başında üniversite akıllı kart biriminden alınan toplu öğrenci ve personel bilgileri ile bunlara ait MIFARE kart bilgileri sisteme aktarılmaktadır.

\begin{tabular}{|c|c|c|}
\hline \multicolumn{2}{|l|}{ DEÜ ïiBF Fakülte Bilgi Sistemi } & \multirow{6}{*}{$\begin{array}{c}\text { IKT1001 } \\
\text { IKTISADA GIRIŞ I } \\
\text { Pazartesi } \\
\text { UTKU UTKULU } \\
\text { ŞUBE: } 2 \\
\text { [12:55:00-15:40:00] }\end{array}$} \\
\hline Kullanıcı Paneli & & \\
\hline 四 Ders Devam Durumu < & & \\
\hline & & \\
\hline 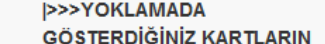 & & \\
\hline DÖKÜMÜNÜ GÖRMEK IÇiN & & \\
\hline TIKLAYINIZ & 2017-09-18 & 2017-09-18 \\
\hline \multirow{3}{*}{$\begin{array}{l}\text { ATA1001 - Atatürk İlkeleri ve } \\
\text { İnkilap Tarihi I }\end{array}$} & 2017-09-22 & 1. SINIF ÖĞRENCILERINE İLK HAFTA MUAF \\
\hline & 2017-09-25 & $2017-09-25$ \\
\hline & 2017-09-29 & YOKLAMA AÇILMADI \\
\hline BDE1001 - Beden Eğitimi I & 2017-10-02 & $2017-10-02$ \\
\hline \multirow{2}{*}{$\begin{array}{l}\text { IBF1001 - HUKUKUN TEMEL } \\
\text { KAVRAMLARI }\end{array}$} & 2017-10-06 & DERSTE YOK \\
\hline & 2017-10-09 & $2017-10-09$ \\
\hline \multirow{2}{*}{ IBF1003 - SOSYAL PSIKOLOJI } & 2017-10-13 & DERSTE \\
\hline & 2017-10-16 & $2017-10-16$ \\
\hline IBF1005 - MATEMATIKI & 2017-10-20 & DERSTE \\
\hline \multirow[b]{2}{*}{ IKT1001 - IKKTISADA GIRIŞ I } & 2017-10-23 & $2017-10-23$ \\
\hline & 2017-10-27 & DERSTE \\
\hline ISL1001 - İ̧̧LETME BíLIMi । & $2017-10-30$ & $2017-10-30$ \\
\hline & 2017-11-03 & DERSTE \\
\hline & 2017-11-06 & $2017-11-06$ \\
\hline MUHASEBE I & 2017-11-10 & ARA SINAV \\
\hline TDL1001 - Türk Dili I & 2017-11-13 & $2017-11-13$ \\
\hline \multirow{3}{*}{$\begin{array}{l}\text { YDI1009 - YabancI Dil I } \\
\text { (Ingilizce) }\end{array}$} & 2017-11-17 & ARA SINAV \\
\hline & 2017-11-20 & $2017-11-20$ \\
\hline & 2017-11-24 & DERSTE YOK \\
\hline \& DEBis Şifrenizi Değiștirin & 2017-11-27 & $2017-11-27$ \\
\hline \& Dönem Notlarınıı Görüntüleyin & 2017-12-01 & DERSTE YOK \\
\hline \& Not Dökümünüz & 2017-12-04 & $2017-12-04$ \\
\hline \multirow[b]{2}{*}{ \& Debis Giriş } & 2017-12-08 & DERSTE YOK \\
\hline & 2017-12-11 & $2017-12-11$ \\
\hline \& Web Kayit Sayfası & 2017-12-15 & DERSTE YOK \\
\hline \multirow{2}{*}{ Eூ Güvenli Çıkıș } & $2017-12-18$ & $2017-12-18$ \\
\hline & 2017-12-22 & DERSTE YOK \\
\hline
\end{tabular}

Şekil 6. Öğrenci ders devam takip sistemi durum görüntüleme ekranları 
Yarıyıl içinde öğrencilerin kartlarını kaybetmeleri veya kartın özelliğinin yitirecek şekilde zarar görmesi gibi durumlarda öğrencilerin bu kartlarını yenilemeleri talep edilmektedir. Bu işlemin gerçekleştirilmesi sonrası ise yeni kartın sisteme tanitılması gerekmektedir. Bunun gibi bilgi giriși ve güncellemesi işlemlerinin kolaylıkla yapılması amaciyla Visual Studio.Net geliştirme ortamı üzerinde $\mathrm{CH}$ programlama dili kullanılarak bir yönetim paneli geliştirilmiştir. Yönetim panelinden gerçekleștirilebilen işlemlere öğrenci ve öğretim elemanlarının kartlarının tanımlanması, muafiyet ve izin bilgilerinin girilmesi, ders programlarının tanımlanması ve öğrencilerin kayıtlandıkları derslerin aktarılması örnek olarak verilebilir. Bu yazılım vasıtası ile öğrencilere ait kart bilgisi değişiklikleri de veri tabanında güncellenebilmektedir. $\mathrm{Bu}$ işlemler yetkili bir personel tarafindan gerçekleştirilmektedir. Aynı zamanda bu işlemi gerçekleștiren personel, geliștirilen yazılım sayesinde öğrencinin kayıtlandığı dersleri görebilmekte, sınıflarda öğrencinin terminalde okuttuğu kart bilgilerini döküm halinde alabilmekte ve derslere devam durumunu inceleyebilmektedir.

\subsection{Veri madenciliği modülü}

Ana sunucu veritabanı üzerinde kayıtlanan veriler dönem sonlarında oluşturulmuş veri madenciliği aracı ile işlenmekte ve üretilen sonuçlar analiz edilmektedir. $\mathrm{Bu}$ araç ihtiyaç duyduğu temel bilgileri veritabanı üzerinden alarak veri madenciliği yöntemlerinden Apriori algoritmasını kullanmakta ve ilişkisel kurallar çıkarmaktadır. Bu ilişskiler dönemsel olarak veya daha geniş zaman aralıkları için öğrenci başarı durumlarını etkileyen faktörlerin ve devamsızlık davranışlarının nedenlerinin tespitinde kullanılmaktadır. Dalkılıç ve Aydın'ın (2017) yaptığı çalışmada bu bilgi sisteminde kullanılan veri madenciliği yöntemi detaylı bir şekilde verilmiştir [4].

\section{Tartışma ve Sonuç}

Öğrenci ders devam kontrolü halen birçok eğitim öğretim kurumunda imza toplama, dersteki öğrencileri sayma ve seslenerek kontrol gibi geleneksel yöntemlerle yapılmaktadır. Gelișen teknoloji ile birçok yeni imkân ortaya çımış ve her alanda olduğu gibi derse katılımın takibi içinde kullanılmaya bașlanmıștır. Bu çalıșmada teknolojinin sunduğu imkânlardan birisi olan temassız akıllı kartlar ile öğrencilerin derse devamları takip edilebileceği bir sistem tasarlanmış ve uygulanmıştır. Bu sistemin kullanılması ile ekonomik, sürdürülebilir, güvenli ve hızlı bir çözüm üretilmiştir. Öğretim elemanlarının sorumluluğunda olan öğrencilerin derslere devamlarının kontrol edilmesi bir bilgi sistemi vasıtası ile gerçekleștirilebilmektedir. $\mathrm{Bu}$ da öğretim elemanının asli görevi olan eğitim-öğretim faaliyetlerine daha çok odaklanmasına imkân sağlamaktadır. Öğrenciler de günlük yaşamın yoğunluğu arasında öğretim elemanına ulaşma ihtiyacı hissetmeden derslere devamlarını çevrimiçi olarak her türlü cihaz üzerinden takip edebilmektedirler. $\mathrm{Bu}$ sistem Dokuz Eylül Üniversitesi İktisadi ve İdari Bilimler Fakültesi bünyesinde yer alan yaklaşık 50 adet sınıfta kurulmuş ve aktif olarak kullanılmaya başlanmıștır. Yapılan incelemelerde özellikle 200 kişilik bir sınıfta klasik yöntemlerle yaklaşık 10 - 15 dakika süren bir yoklama işlemi, bu sayede en az hata ile yaklaşık 5 dakika gibi bir sürede tamamlanmaktadır. Ayrıca öğretim elemanının öğrencilerin devam durumlarını takip etmesi, hesaplaması ve her sorunda direkt olarak diyalog içinde olması gibi durumlar ortadan kalktığından ciddi anlamda kolaylık sağlamaktadır. Zaman bakımından 
getirdiği fayda yanında klasik yöntemlerle takip işlemi ciddi manada kâğıt israfına yol açmaktadır. Elektronik ortamda yürütülen işlemler kâğıt kullanımını ortadan kaldırmaktadır. Ayrıca idari süreçlerde de ciddi rahatlamalar yaşanmaktadır. Her türlü bilgi ve belge internet ortamında öğrenciye sunulduğundan öğretim elemanları ve öğrenci işleri ofisi çalışanları öğrencilerin soruları veya talepleri ile daha az meşgul olmaktadırlar.

Böyle bir bilgi sistemi bütünleşik olarak üzerinde bulundurduğu özgün veri madenciliği analiz aracı vasıtası ile çeşitli analizler yapılmasına imkân tanımaktadır. Özellikle devamsızlık yapan öğrencilerin fakülte, okul veya üniversite düzeyinde tespiti, bunların genel özelliklerinin çıkarılması ve çeşitli sonuçlara ulaşılması kolaylaşmaktadır. Elde edilen verilerin incelenmesi ile devam durumlarından öğrencilerin başarılarının etkilenip etkilenmediği, etkileniyor ise bunlar için alınacak önlemler belirlenebilmektedir. Devamsızlıklar haftalık bazda tüm eğitim öğretim kurumunda merkezi olarak takip edilebildiğinden hafta bazlı öğrencinin gidişatı izlenebilmektedir. Ayrıca öğretim elemanlarının performansının takip edilmesine olanak sağlayan bu sistem hem öğrenci hem de öğreticinin takibi anlamına gelmektedir. Öğreticinin derslerini idarenin haberi dışında tatil edip etmediğini görebilmek mümkündür. Ek olarak derslerine katılımın düşük olduğu öğretim elemanlarının incelenmesi veya sorunun tespiti için yol gösterici olmaktadır.

Kurulan veya tasarlanan benzer diğer devam takip sistemlerinde öğrencinin başkası yerine kart göstermesi gibi durumlar için çözümlerinin uygulanabilirliği düşüktür. $\mathrm{Bu}$ uygulamada öğretim elemanı ders başında, arasında veya ortasında yoklamayı aktif edebilmektedir. $\mathrm{Bu}$ işlem sonrası kart gösterimleri esnasında öğrencilerin yanında bulunur ve tüm öğrencilere kartlarını gösterdikten sonra işlemi sonlandırır. İşlemin bu şekilde yürümesi öğrencilerin başkası adına kart göstermesi veya kart gösterimi sonrası dersi terk etmesi ihtimalini düşürmektedir.

\section{Teşekkür}

$\mathrm{Bu}$ çalıșmaların yürütüldüğü Dokuz Eylül Üniversitesi İktisadi ve İdari Bilimler Fakültesi yönetimi ve çalışanlarına teşekkür ederiz.

\section{Kaynakça}

[1] Silah, M. 2003. Üniversite Öğrencilerinin Akademik Başarılarını Etkileyen Çeşitli Nedenler Arasından Süreksiz Durumluk Kaygisının Yeri ve Önemi, Eğitim Araştırmaları Dergisi, Cilt. 10, s. 102-115.

[2] Türnüklü, A., Zoraloğlu, Y., Gemici, Y. 2001. İlköğretim Okullarında Okul Yönetimine Yansıyan Disiplin Sorunları, Kuram ve Uygulamada Eğitim Yönetim Dergisi, Cilt. 27, s. 417-441.

[3] Geçtürk, Ö. 2001. Meslek ve Anadolu Meslek Liselerinde Öğrenci Başarısını Etkileyen Faktörler. Marmara Üniversitesi, Fen Bilimleri Enstitüsü, Yüksek lisans tezi, İstanbul.

[4] Dalkılıç, F., Aydın, Ö. 2017. Dokuz Eylül Üniversitesi İktisadi ve İdari Bilimler Fakültesi Öğrencilerinin Devamsızlık Davranışlarını Etkileyen Faktörler, Yükseköğretim ve Bilim Dergisi, Cilt. 7(3), s. 546553, DOI: 10.5961/jhes.2017.231.

[5] Altınkurt, Y. 2008. Öğrenci Devamsızlıklarının Nedenleri Ve Devamsızlı̆̆ın Akademik Başarıya Olan Etkisi, Dumlupınar 
Üniversitesi Sosyal Bilimler Dergisi, Cilt. 20, s. 129-142.

[6] Öztekin, Ö. 2013. Lise Öğrencilerinin Devamsızlık Nedenlerinin İncelenmesi. Eskişehir Osmangazi Üniversitesi, Eğitim Bilimleri Enstitüsü, Yüksek Lisans Tezi, Eskișehir.

[7] Jerald, C.D. 2006. Identifying Potential Dropouts: Key Lessons For Building an Early Warning Data System, American Diploma Project Network, Achieve, Inc .

[8] Bülbül, H.İ., Küçükali, M., Köseci, S. 2004. Uzaktan Sinav ve Kimlik Algılama Sistemi, Gazi Üniversitesi Endüstriyel Sanatlar Eğitim Fakültesi Dergisi, Cilt. 14, s. 36-45.

[9] Hanehalkı Bilişim Teknolojileri Kullanım Araştırması: Bilgi Toplumu İstatistikleri: 2004-2017, Türkiye İstatistik Kurumu, http://www.tuik.gov.tr/PreIstatisti kTablo.do?istab_id=1615, (Erişim Tarihi: 09.01.2018).

[10] Akçay, M. Cetinkaya, H.H. 2011. Kampüslerde Uygulanan Yeni Biyometrik Sistemler. Akademik Bilişim'11 - XIII. Akademik Bilişim Konferansı Bildiriler Bildirileri, 2 4 Şubat, Malatya, s. 385-389.

[11] Kainz, O., Cymbalak, D., Lamer, J., Jakab, F. 2014. Visual System for Student Attendance Monitoring with Non-standard Situation Detection. 12th IEEE International Conference on Emerging eLearning Technologies and Applications, 4-5 Aralık, Slovakia, 221-226.

[12] Benyo, B., Sodor, B., Doktor, T., Fordos, G. 2012. Student Attendance Monitoring at the University Using NFC. Wireless Telecommunications Symposium (WTS 2012), 18-20 Nisan, Londra, 1-5.

[13] Krisha, C.S., Sumanth, N., Prasad, C.R. 2013. RFID based Student Monitoring and Attendance Tracking System. The $4^{\text {th }}$
International Conference on Computing, Communications and Networking Technologies (ICCCNT), 4-6 Temmuz, Tiruchengode, India, 1-5.

[14] Silva, F., Filipe, V., Pereira, A. 2008. Automatic Control of Students' Attendance in Classrooms Using RFID. The $3^{\text {rd }}$ International Conference on Systems and Networks Communications, 26-31 October, Malta, 384-389.

[15] Patel, R., Patel, N., Gajjar, M. 2012. Online Students' Attendance Monitoring System in Classroom Using Radio Frequency Identification Technology: A Proposed System Framework, International Journal of Emerging Technology and Advanced Engineering, Cilt: 2, s. 61-66.

[16] Çakır, A., Kaygısız, H. 2011. Kablosuz Öğrenci Yoklama Kontrol Sistemi. The $6^{\text {th }}$ International Advanced Technologies Symposium (IATS'11), 16-18 Mayıs, Elazığ, 33-35.

[17] Yılmaz, C., Özdil, T., Tümtürk, A., Tümtürk, E. 2011. Celal Bayar Üniversitesi İktisadi ve İdari Bilimler Fakültesi'nde Okutulan Üretim Yönetimi Derslerinde Öğrencilerin Devamı İle Başarı Notları Arasındaki İlișkinin İncelenmesi. XI. Üretim Araştırmaları Sempozyumu, 23- 24 Haziran, İstanbul, 83-91.

[18] Yılmaz, M.B., Orhan, F. 2011. Karma Öğrenme Ortamındaki Üniversite Öğrencilerinin Akademik Başarılarının, Web Materyalini Kullanma Davranışlarının ve Devamlarının Öğrenme Yaklaşımlarına Göre Değerlendirilmesi, International Journal of Human Sciences, Cilt: 8(2), s. 1028-1048.

[19] Özbaș, M. 2010. İlköğretim Okullarında Öğrenci Devamsızlığının Nedenleri, Eğitim 
ve Bilim Dergisi, Cilt. 35(156), s. 32-44.

[20] Gökyer, N. 2012. Ortaöğretim Okullarındaki Devamsızlık Nedenlerine İlișkin Öğrenci Görüşleri, Kastamonu Eğitim Dergisi, Cilt: 20(3), s.913-938.

[21] Dokuz Eylül Üniversitesi Ön Lisans ve Lisans Öğretim ve Sınav Yönetmeliğinde Değisşiklik Yapılmasına Dair Yönetmelik, T.C. Resmi Gazete, Başbakanlık Mevzuatı Geliştirme ve Yayın Genel Müdürlüğü, http://www.resmigazete.gov.tr/es kiler/2012/08/20120813-3.htm, (Erișim Tarihi: 09.01.2018).

[22] Semiconductors, N. X. P., AN10833MIFARE Type Identification Procedure. http://www.nxp.com/documents/ application_note/AN10833.pdf, 2016, (Erişim Tarihi: 09.01.2018).

[23] Kennedy, P.R., Hall, T.G., Hardy, D.A. 2000. U.S. Patent No. 6,084,968. Washington, DC: U.S. Patent and Trademark Office.
[24] Hughes, J.M. 2016. Arduino: A Technical Reference: A Handbook for Technicians, Engineers, and Makers. O'Reilly Media, Inc.., 638s, ISBN: 978-1-118-46446-5.

[25] Upton, E., Halfacree, G. 2014. Raspberry Pi user guide. John Wiley \& Sons. 152s, ISBN: 978-1118-46446-5.

[26] MFRC522, https://www.nxp.com/documents /data_sheet/MFRC522.pdf, (Erişim Tarihi: 09.01.2018).

[27] ART63M, http://www.artelektronik.com/ur un-art63m.html, (Erişim Tarihi: 09.01.2018).

[28] Howes, T., Kille, S., Yeong, W. 1995, Lightweight Directory Access Protocol (LDAP). RFC1777, Performance Systems International, University of Michigan, ISODE Consortium.

[29] Clifton, B. 2012. Advanced Web Metrics with Google Analytics. John Wiley \& Sons, 600s, ISBN: 978111816844-8. 